\title{
American and international studies: Infernet resources
}

\author{
By L. Stephen Perry
}

\section{Join the discussions and debates on political and social topics}

- oth American studies and international - studies have benefited immensely from having a multiplicity of resources and sites available on the Internet. Although these two fields are distinct in many obvious ways, they both share a robust interdisciplinary approach to their respective areas of inquiry in such fields as history, literature, folklore, politics, popular culture, economics, mass media analyses, among a host of other related topics. Both also share a constancy of academic discourse (grounded in similar theoretical approaches) which is why it makes sense (at least in Internet terms) to group them loosely together as being two sides of roughly the same coin. For researchers specifically interested in both American studies and international studies, these sites include anything from discussion groups to full-text speeches and documentsall seamlessly connected by a variety of hypertext links pointing to an abundance of even more relevant online resources.

As a separate field, American studies emerged out of the historical crises of the 1930s and 1940s. ${ }^{1}$ However, the field developed its first real growth in the climate of nationalism and patriotism during World War II and the immediate postwar era, as that period was one of the main agents responsible for the defense of uniquely American values and served as the spawning ground for the study of American culture and society around the world, a situation that also intertwined with the emergence of international and area studies.
The field's most creative disciplinary turning points have come in response to subsequent social, cultural, and political problems. Indeed, one of its leading practitioners has argued that as a separate area of academic inquiry, American studies has been particularly leavened by a long heritage of scholarly efforts to deal with the complexity of cultural and social differences that the emerging nation faced with successive waves of immigration. ${ }^{3}$

Indeed, scholars of both American and international studies argue convincingly that questions of national identity are crucial to cultures, and that both disciplines have an important role to play by applying the categories raised within European cultural theory either to the uniquely American or to the broadly international context. These scholars also assert that both disciplines have raised new questions emerging from the particular complexities and contradictions within American or other national cultures and that as fields, they have been at their best when engaged in dialogue with "the complex and conflicted realities of American life and culture." 4

Both American Studies and International Studies have positioned themselves within academia as a result of their shared concerns. Some of these include a desire for entering into the "texture of a foreign society" for the purpose of integrating scholarly work and perspectives into a larger story, thereby providing a "fresh synthesis" for historical purposes.

Both disciplines, in short, are anchored by the premise that the international dimensions of all area studies programs are immense, an argument championed by the former chair of the U.S. Foreign Relations Committee, J. William Fulbright, when he and other scholars have noted that the international dimensions of such 


\section{SOME SCIENTIFIC}

ACHIEVEMENTS

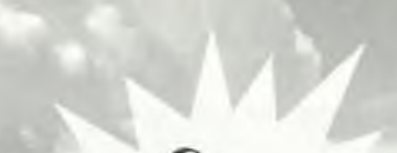

\section{SPEAK VOLUMES}
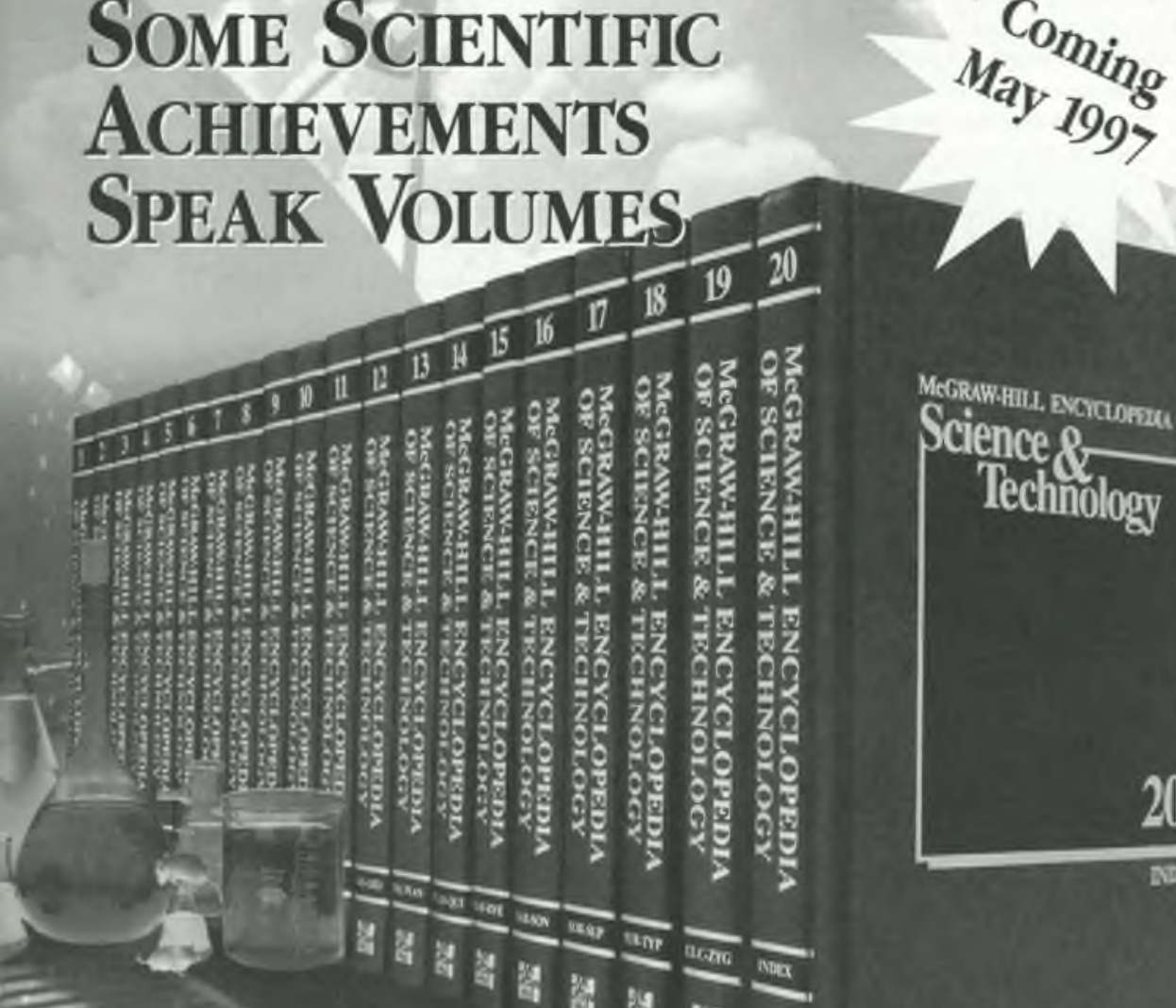

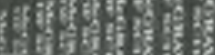
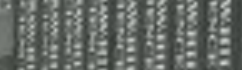

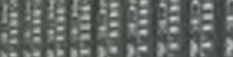

पु
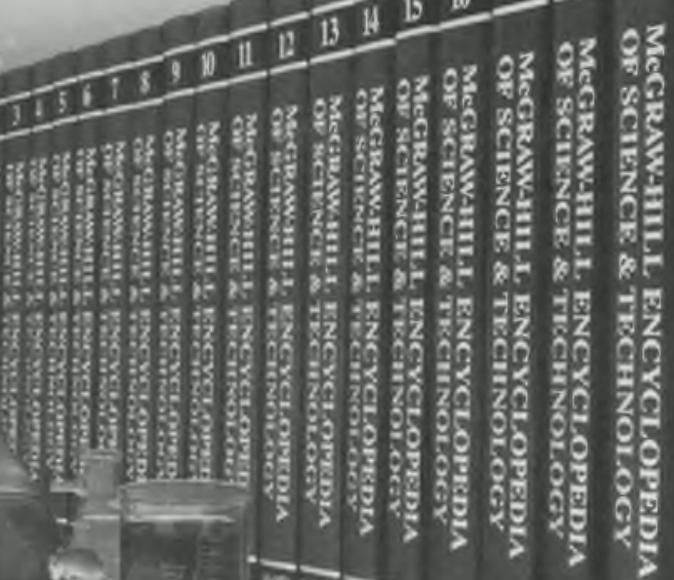

93.
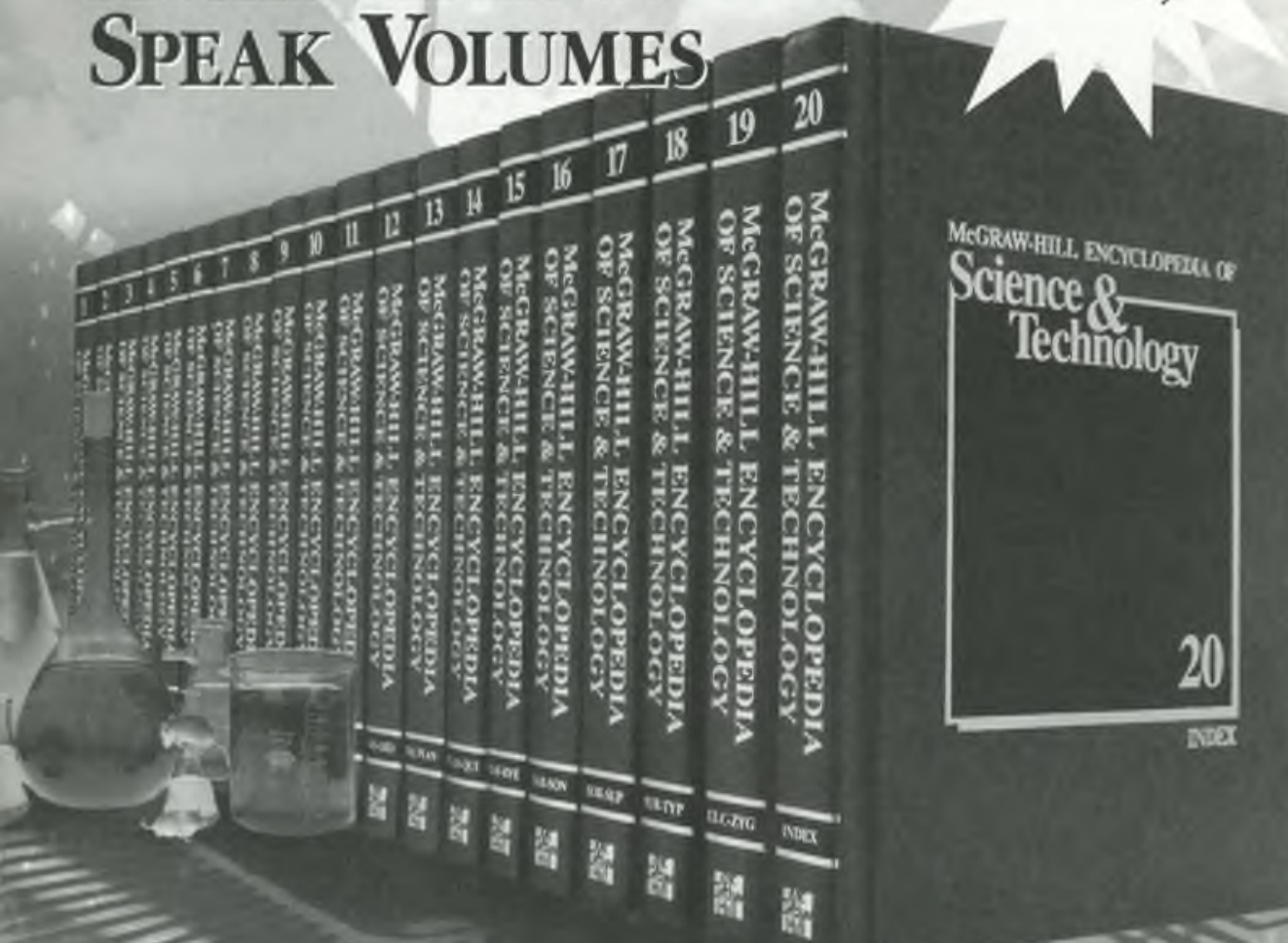

N2x

\section{Announcing MaGraw-Hitl Encyclopedia of Science \& Technology, 8th Edition}

In every library there should be a first place students, researchers, educatons and librarians turn to find information on any scientific or technical subject. A place where the inspiration for starting a rescarch project, the supporting evidence for a paper, or the authoritative answer to an intriguing question can always be found. More than ever, the new Eighth Edition of the McGraw.Hill Encyclopedia of Science \& Tecbnology is that place, with thousands of new and revised articles and illustrations, and completely revised bibliographies, No library should be without the McGraw-Hill Encyclopedia of Science and Tecbnology. Eighth Edition-the first science reference Special frepepubllcation OfJerSave Over $\$ 200$ that's a scientific achievement in its own right.

rere-publication price 51.750 ibrough $5.31,97$ S1.295 theweafor: Isin: 0-07.911504-7 
programs help counter isolation, and with it, the misinterpretations and antagonism such isolation does so much to encourage. Both disciplines contribute towards the stimulation of a rich, cross-cultural communication. ${ }^{6}$

It is my hope that the following compilation of Internet resources will aid in this cross-cultural communication and make it easier for the scholars and practitioners of both fields to tap into the exciting research advances that both fronts have developed so fruitfully over the past 25 years.

\section{Listservs and newsgroups}

There is an overwhelming number of listservs that legitimately could be included here, and any one of these could claim a rightful place on this resource guide, especially given the very broad concerns of scholars and practitioners in these two wide-ranging fields. However, due to severe space constraints, my modus operandi has been to choose those listservs that best represent the principal resource that scholars in these two disciplines would tend to choose over others. In most cases, I have eschewed the country-specific in favor of larger geographical regions or concerns. Disappointed practitioners who desire a much more comprehensive resource guide to listservs are directed to the Directory of Electronic Joumals, Newsletters and Academic Discussion Lists, 6th ed. (Washington, D.C.: Association of Research Libraries, 1996). The electronic version of this guide is also available on the Internet (http://n2h2.com/ KOVACS) and has the additional advantage of being keyword searchable, and updated more often than the print version. (Electronic journals and newsletters are keyword searchable via http://arl.cni.org/scomm/edir/.)

\section{Listservs-American studies}

- H-AMSTDY. The principal American Studies ListServ located at the University of Illinois at Chicago. Provides a major electronic forum for many American studies scholars. $A C$ cess: listserv@H-Net.msu.edu.

- AFAM-L. A discussion group for the "African American research forum for exchange of information, ideas and concerns of African American Studies and of African Americans in general." Access: LISTSERV@MIZZOU1. MISSOURI.EDU

- AMERSTDY. Another useful listserv for American studies scholars and students. Access: LISTSERV@MIAMIU.MUOHIO.EDU.
- INTERCUL. A discussion list for intercultural/crosscultural communication that features many wide-ranging issues being batted around. Access: COMSERV@VM.ITS.VPI.EDU.

- INTERDIS. A useful discussion group for all aspects of interdisciplinary studies, including issues related to cross-collaboration between the disciplines. Access: LISTSERV@MIAMIU. MUOHIO.EDU

\section{Listservs-international studies}

- AMERICAN-STUDIES. Primarily for British scholars working in the field of American studies. Access: MAILBASE@MAILBASE.AC.UK. To reach the moderator, write to: americanstudies-request@mailbase.ac.uk.

- SEANET-L. Southeast Asian Studies List. Current threads running through this list are Vietnam, trade and political relations, economics, and business. Access: LISTSERV@NUSVM. NUS.SG

- LASNET. Latin American Studies Network. A "collective" and active electronic workshop for professionals, scholars, and practitioners engaged in Latin American life, culture, and politics. Access: LASNET-REQUEST@EMX. UTEXAS.EDU.

- AFRICA-L. "Forum for the discussion of the interests of African peoples (in Africa, and expatriate), and for those with an interest in the African continent and her peoples." Access: LISTSERV@VTVM1.CC.VT.EDU

- CENASIA. A discussion group for the Central Asian republics of the former Soviet Union. Topics discussed are more political than cultural. Access. LISTSERV@MUSICA.MCGILL.CA.

- FSU. Concentrates on developments throughout the former Soviet Union, including regional issues, politics, religion, the environment, and both political and economic reform. Access: FSU-REQUEST@SOVSET.ORG.

- ETHNOHIS. A useful listserv for those scholars wishing to examine the convergence of both ethnology and history. A stated purpose of this listserv is to serve as a stimulus for productive interdisciplinary approaches. Access: LISTSERV@HEARN.NIC.SURFNET.NL.

\section{Usenet usegroups}

Usenet newsgroups can be generally accessed by typing either " $r n$ " or "nn" at the Internet shell prompt of your local computer account. System administrators should be consulted, however, for other local options they may have provided for accessing these newsgroups. 
Many of the usenet groups related to American or international studies have a decidedly anthropological slant as they tend to focus on the cultures and societies of the various ethnic or indigenous groups of the world. These include (but are not limited to): soc.culture. mexican; soc.culture.peru; soc.culture.latinamerica; soc.culture.indian.american; soc.culture.native.american; soc.culture.spain; soc.culture.african.american; soc.culture.misc; alt.appalachian; soc.culture.australian; soc.culture.caribbean; soc.culture.turkish; soc.culture.canada; soc.culture.japan; soc.culture.maghreb (about North African society and culture); soc.culture.yugoslavia; soc.culture.african; soc.culture.nordic; soc.culture.soviet; soc.culture.native (about the aboriginal peoples around the world); soc.culture.asian.american; soc.culture.usa; soc.culture.celtic; etc.

\section{Electronic journals}

The principal electronic journal for the field is Journal of American Studies (http://www.cup. cam.ac.uk/Journals/JNLSCAT95/ams/ams.html) However, for the interested scholar seeking other electronic journals in the vast arena of American and international studies, it would be criminal not to comment on the abundance of electronic journals available on the Internet. It seems that every day at least two or three electronic journals make their digital debut. One major listserv is devoted solely to announcing these new electronic journals and newsletters (owner-newjour@ccat.sas.upenn.edu). To subscribe to this service, send e-mail to MJD@CCAT. SAS.UPENN.EDU). This listserv also maintains a keyword searchable archive of the more than 250 electronic journals it has reported on since 1993 (http://gort.ucsd.edu/newjour/).

In addition, there are a number of other gopher and World Wide Web sites that also are either completely or at least partially devoted to organizing and providing keyword searchable archives of electronic journals. The major ones at present are listed below.

\section{Collections of electronic journals}

- The American Communication Association has done a yeoman's job by collecting a number of sites where thousands of electronic books, journals, texts, and similar electronic conversion projects may be easily located at http://cavern.uark.edu/comminfo/www/ books.html.
- The University of Arkansas Libraries homepage has a module devoted to electronic resources at the URL: http://cavern.uark.edu/ libinfo/electronic/ejournals.html.

\section{Telnet resources}

The Department of History and Academic Computer Services at the University of Kansas provides a central information server for historians which features a connection to online library catalogs, some databases, FTP sites that contain materials relevant to historical studies as well as a full-text document archive, access to worldwide gophers, several works on the use of the Internet, and some Gutenberg electronic texts. Access: Telnet to hnsource.cc.ukans.edu; login: history; no password is required.

\section{FTP resources}

The Fourth World Documentation Project gathers documents from nations and indigenous groups around the world for processing and distribution. These documents form an electronic archive of voices from the Fourth World Project, with valuable documentary information on Africa, North and South America, Asia, and the Pacific, with other collections in progress. Access: FTP to fir.cic.net; then type cd /Politics/Fourth.World (Fourth World Documentation Project); then type dir for a listing of the contents.

This site is also mirrored by a Web site at the University of Michigan. Access: http://www. halycon.com/FWDP/fwdp.html.

\section{Gopher resources}

- Access: gopher://marvel.loc.gov:2069/7. Type "american studies" after receiving the message "Enter Database Search String." Offered by the Library of Congress, this details holdings in select component areas of American studies such as American literature, Indians of North America, African American studies, American political science, etc. An excellent resource for all scholars in American studies.

- Access: gopher://hearn.nic.surfnet.nl/. Presents a convenient listing of listservs in all subject areas. This global list "of listserv lists" is updated daily.

\section{World Wide Web resources}

- American Studies Association Crossroads Project. The Crossroads venture of the American Studies Association is being developed out of the Center for Electronic Projects 
at Georgetown University. This undertaking is an "international Internet and curriculum innovation project that includes three main components: scholarly and institutional information for the international American Studies community; experimental curriculum revision designs for key American Studies courses at select test sites; workshops and institutes at various levels to promote serious innovation in American Studies curricula especially related to the integration of new technologies. . . ." Access: http:// www.georgetown.edu/crossroads/asw

- Yahoo American Studies Web Site. Includes links to more than 350 American studies sites and to related information servers in the fields of literature, history, arts and material culture, religion and philosophy, and social sciences. It also has pointers to Internet sites for the American South, the American Studies Working Group, and Canadian Studies. $A C$ cess: http://www.yahoo.com/text/Social_ Science/American Stuklies.

- World Wide Web Server for Cultural Studies. Includes black studies, cultural and ethnic collections, a Center for the Study of Southern Culture, future culture, National Indian Policy Center, and numerous other listings. Access: http://galaxy.einet.net/galaxy/ Community/Culture.html.

- WWW Virtual Library: Museums and Popular Culture Collections. Access: hittp:// www.museum.state.il.us/vlmp/.

- Film Studies Web Server (also includes many items on popular culture). From the American Communication Association, this site includes a vast array of Internet resources such as film databases; access to the homepages of actors, actresses, and directors; Academy Award winners; specific information on films and film reviews; and numerous links to other film and popular culture sites. Very comprehensive and up-to-date, this is one of the very best resources for film scholars. Access: http:/cavern.uark.edu/ comminfo/www/film.html.

- The homepage for the American Communication Association (ACA) with links to a multitude of other related resources may be found at http://cavern.uark.edu/comminfo/ www/ACA.html. The ACA homepage also includes many items on mass media such as television, radio, movies, popular culture analyses, etc.

\section{- World Wide Web Servers for Women's}

Studies. Access: http://sunsite.unc.edu/cheryb/ women/wshome.html and http://www.ibd.nro $\mathrm{ca} / \sim$ mansfield/feminism.html (includes feminism and women's resources).

- World Wide Web Server for History (covers all chronological periods and all regions). Access: http://history.cc.ukans.edu/history/WWW_history_main.html.

- Historical Text Archive. Contains full texts of speeches and other historical documents from all time periods. Access: http:// www.msstate.edu/Archives/History/

- H-Net. Provides online access to a variety of Web sites in the humanities (including history) and social sciences for scholars, students, teachers, and practitioners in all related fields. An excellent site for both American and international studies. More than 75 electronic discussion groups are listed for broad access to a variety of scholarly networks; a list of lists helps pinpoint a particular topic. Includes job listings and relevant professional associations as well. Access: http://h-net.msu.edu.

- World Wide Web Server listing government and international resources. In addition to a valuable listing of government and international agencies, this site provides a useful topical breakdown of Internet resources in general. Access: http://www.eit.com/web/ netservices.html.

- Library of Congress World Wide Web Server. Provides convenient access to the online Library of Congress catalog, exhibits, THOMAS (for current status of legislation), and a variety of online ready reference sources, including country studies and area handbooks. Access: http://lcweb.loc.gov.

- International Studies Home Page. The main resource for students and scholars of international studies, it includes links to agencies. Access: http://www.aaln.org/vcl/electronics/etc/acad/intstud.html.

- Guide to Resources in and Grants for International Studies. Includes such topics as institutional support, grants for faculty, and resources for academic disciplines. Access: http: //www.umich.edu/ iinet/ii/GuidetoResources 1994.html.

- International and Area Studies. Contains Internet resources for foreign languages and cultures, think tanks around the world, area studies resources, and country-specific issues, among other topics. Access: http://www.clark. net/pub/lschank/web/country.html

- African Studies World Wide Web Server. Access: http://www.sas.upenn.edu/ African_Studies/AS.html. 
- Asian Studies World Wide Web Server.

Part of the WWW Virtual Library Series, this site also includes Australia, New Zealand, and the Pacific. Access: http://coombs.anu.edu.au/ WWWVL-AsianStudies.html.

- Latin American Studies World Wide Web Server: Access: http://lanic.utexas.edu/.

- Area and Regional Studies Scholarly Resources (includes all interdisciplinary area stuclies programs and related international studies disciplines). Access: http://humanitas.ucsb. edu/shuttle/area.html.

- Middle Eastern Studies World Wide Web Server. Includes pointers to all countries in the region. Access: http://menic.utexas.edu/ mes.html.

- Russian and East European Studies World Wide Web Server. Access: http:// www.pitt.edu/ cjp/rees.html.

- United Nations World Wide Web Server. For one-stop information on all aspects of the United Nations, including its constituent parts, plus work in progress. Access: http:// www.un.org/.

- Web Server for Scholarly Societies: An Electronic Guide. A convenient way to locate the electronic addresses, missions, and relevant information of various scholarly societies around the world. Access: http://www. lib.uwaterloo.ca/ society/overview. html.

\section{Notes}

1. George Lipsitz, "Listening to Learn and Learning to Listen: Popular Culture, Cultural Theory and American Studies," American Quarterly 42 (December 1990): 615-36.

2. Allen F. Davis, "The Politics of American Studies," American Quarterly 42 (September 1990): 353-74; and Richard D. Lambert, "Blurring the Disciplinary Boundaries: Ared Studies in the United States," American Bebavioral Scientist 33 (July/August 1990): 712-32.

3. Alice Kessler-Harris, "Cultural Locations: Positioning American Studies in the Great Debate," American Quarterly 44 (September 1992): 304.

4. Lipsitz, "Listening to Learn and Learning to Listen," 615-36.

5. Robert I. McMahon, "The Study of American Foreign Relations: National History or International History," Diplomatic History 14 (fall 1990): 556.

6. Richard P. Horwitz, "The Politics of International American Studies," American Studies International 31 (April 1993): 89-116.

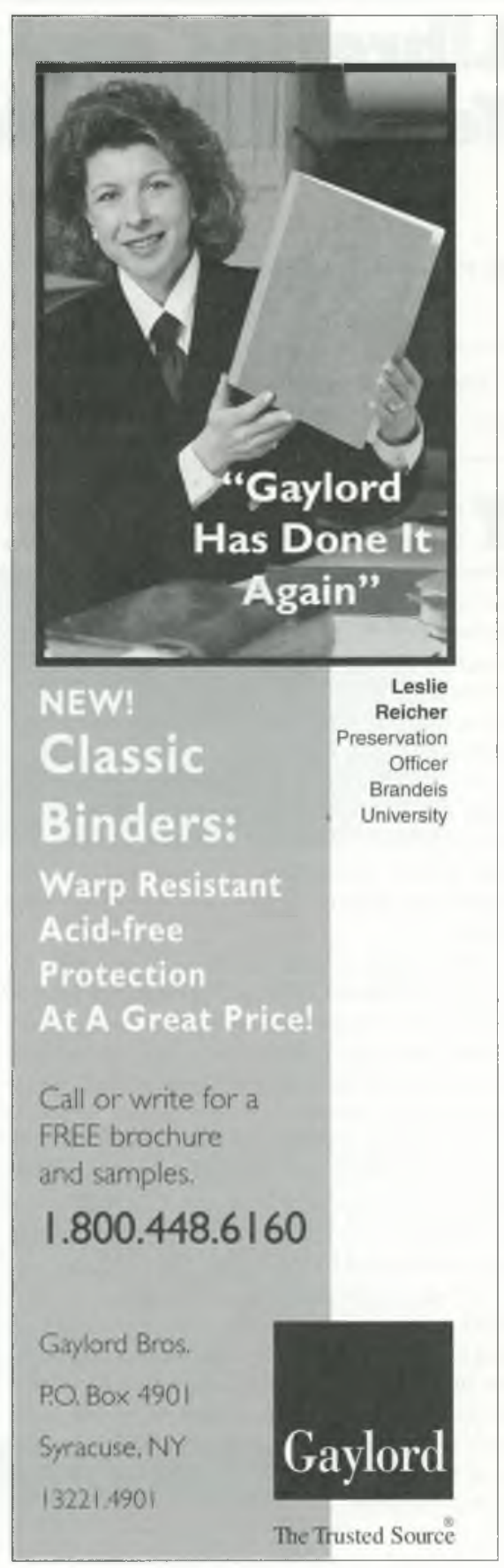

